\title{
PERSEPSI MAHASISWA TERHADAP PENGGUNAAN E-LEARNING DALAM PEMBELAJARAN BAHASA PEMOGRAMAN DI FAKULTAS TEKNIK UNP
}

\author{
Yeka Hendriyani ${ }^{1}$ \\ Hansi Effendl ${ }^{2}$
}

\begin{abstract}
This study aims to determine students' perceptions of the use of e-learning as a supplement or replacement for face-to-face lectures. The method was conducted by distributing questionnaires to student about the use of e-learning. The questionnaire consists of two instruments, namely : (1) the instrument about student opinion on the Programming Language subject which is taught using elearning, which consists of 33 items ; and (2) general perceptions of students about e-learning which consists of a 30 items. In the first questionnaire, after using e-learning for one semester on Programming Languages course, the students considered that the use of e-learning in terms of learning objectives, learning materials, the rules of the role, interactive aspects, and supporting systems were adequate; whereas in terms of social system of e-learning that was used is still not enough. In the second questionnaire, students should be consulted on e-learning in terms of motivation, ease of use, benefits, efficiency, attractiveness, and a must. The result is that students considered that the use of e-learning as a supplement or as a substitute for face-to-face classroom lectures were motivating, easy to use, useful, efficient, attractive and is a must.
\end{abstract}

Keywords: Perception, E-learning, Supplement

\section{INTISARI}

Penelitian ini bertujuan untuk mengetahui persepsi mahasiswa terhadap pemanfaatan e-learning sebagai suplemen maupun pengganti beberapa perkuliahan tatap muka dalam pembelajaran. Metode yang dilakukan yaitu dengan cara menyebarkan kuesioner untuk mengukur pendapat mahasiswa terhadap pembelajaran menggunakan e-learning dalam pembelajaran. Kuesioner terdiri dari dua instrumen, yaitu: (1) instrumen pendapat mahasiswa tentang pembelajaran pada matakuliah Bahasa Pemrograman menggunakan e-learning, yang terdiri dari 33 butir pernyataan; dan (2) instrumen persepsi mahasiswa secara umum tentang e-learning yang terdiri dari 30 butir pernyataan. Pada kuesioner pertama, setelah menggunakan e-learning selama satu semester pada matakuliah Bahasa Pemrograman, maka mahasiswa menilai bahwa penggunaan e-learning dari segi tujuan pembelajaran, materi pembelajaran, aturan peran, aspek interaktif, dan sistem penunjangnya cukup memadai; sedangkan dari segi sistem sosial mahasiswa menilai e-learning yang digunakan masih belum cukup. Pada kuesioner kedua, mahasiswa dimintai pendapat mengenai e-learning

\footnotetext{
${ }^{1}$ Dosen Jurusan FTI FT UNP

${ }^{2}$ Dosen Jurusan Elektro FT UNP
} 
VOL. 8 NO. 1 Maret 2015

ditinjau dari segi motivasi, kemudahan penggunaan, manfaat, efisiensi, daya tarik, dan suatu keharusan. Hasilnya yaitu mahasiswa menilai bahwa penggunaan e-learning sebagai suplemen maupun sebagai pengganti perkuliahan tatap muka di kelas memotivasi, mudah digunakan, bermanfaat, efisien, menarik dan merupakan suatu keharusan.

Kata Kunci: Persepsi, E-learning, Suplemen 


\section{PENDAHULUAN}

Banyak universitas telah
memanfaatkan e-learning untuk
pembelajarannya, begitu juga
dengan Universitas Negeri Padang
(UNP). Sejak semester Juli-
Desember 2013, UNP meluncurkan
e-learning yang dapat dimanfaatkan
oleh seluruh dosen yang membina
suatu mata kuliah dan mahasiswa
yang terdaftar pada mata kuliah
tersebut. Mahasiswa yang terdaftar
pada suatu mata kuliah tertentu
secara otomatis terdaftar sebagai
peserta perkuliahan dalam e-
learning.

Sebagai universitas negeri, tentu UNP tidak bisa melakukan pembelajaran yang seratus persen berbasis e-learning. Sehingga elearning yang ada hanya bisa dimanfaatkan sebagai suplemen atau sebagai pengganti sebagian perkuliahan yang ada. Istilahnya menurut Robin Mason (1998) dari United Kingdom Open University yaitu perkuliahan yang bersifat "partially online" atau dikenal dengan blended learning. Definisinya seperti yang dituliskan oleh Garrison dan Vaughan (2008:4), blended learning adalah pembelajaran yang memadukan antara komponen online dan komponen tatap muka di kelas.

Pada saat ini penggunaan elearning di UNP maksimal hanya sebagai suplemen dalam pembelajaran, karena walaupun pelatihan penggunaan e-learning terhadap dosen sudah dilakukan, tapi tidak semua dosen ikut dalam pelatihan tersebut. Bagi yang belum ikut dapat mempelajarinya secara otodidak melalui dokumen panduan penggunaan yang ada pada elearning. Dari pihak manajemen, penggunaan e-learning sebagai suplemen pembelajaran juga belum diwajibkan kepada dosen-dosen di UNP. Dosen yang berminat dipersilahkan mempergunakan elearning sebagai media dalam pembelajarannya. Tetapi tidak tertutup kemungkinan suatu saat nanti dosen-dosen UNP diwajibkan menggunakan e-learning sebagai suplemen maupun sebagai pengganti beberapa pertemuan mata kuliahnya.

Sehubungan

dengan penggunaannya sebagai suplemen atau tambahan dalam pembelajaran, e-learning dapat dimanfaatkan untuk memasukkan bahan ajar, memberikan pengumuman kepada mahasiswa, memberikan kuis online, sebagai tempat diskusi secara sinkron (melalui chatting) maupun asinkron (forum diskusi), sebagai tempat mengumpulkan tugas-tugas, dan lain sebagainya.

Penggunaan e-learning dalam pembelajaran cocok dilakukan pada perguruan tinggi. Salah satu filosofi perancangan dan pengembangan elearning yaitu konstruktivisme. Konstruktivisme sebagai paradigma baru pendidikan berpendapat bahwa belajar adalah proses aktif dan konstruktif. Peserta didik adalah konstruktor informasi. Informasi baru dikaitkan dengan pengetahuan yang telah ada sebelumnya, sehingga mental bersifat subjektif. Konstruktivisme menganggap bahwa semua pengetahuan dibangun dari pengetahuan peserta didik sebelumnya, terlepas dari bagaimana seseorang menerima pengetahuan itu. Oleh karena itu dalam konsep konstruktivistik peserta didik yang menjadi aktif menjadi penting.

$$
\text { Cheng (2005:29) dalam }
$$

bukunya "New Paradigm for Reengineering Education: Globalization, Localization, and Individualization" memperlihatkan bahwa saat ini mahasiswalah yang menjadi pusat pembelajaran. Dosen tidak lagi menjadi satu-satunya sumber informasi, tetapi menjadi fasilitator, motivator, katalisator, atau mediator bagi mahasiswa. Mahasiswa dituntut harus bersikap 
aktif, mandiri, inisiatif, analitis dalam belajar. Sehingga pembelajaran yang dikembangkan haruslah berpusat kepada mahasiswa (student-centered), dapat dipelajari secara mandiri (self-learning), fokus kepada bagaimana belajar (how to learn), memiliki sumber yang cukup dalam menunjang pembelajaran (multiple sources), tidak berbatas ruang dan waktu, dan memberikan feedback kepada mahasiswa, serta bersifat interaktif.

Kurikulum 2013 juga menuntut mahasiswa untuk aktif dalam pembelajaran. Selain menguasai kompetensi bidang ilmu, mahasiswa juga dituntut dapat mengembangkan keterampilan generic (softskill) seperti jujur, berfikir kritis, kreatif, mampu bekerja sama dengan orang lain (bekerja berkelompok), problem solver, mampu mengambil keputusan, dan bertanggung jawab terhadap pekerjaannya sendiri atau pekerjaan kelompok. Mata kuliah yang mengajarkan ini tidak ada di universitas, sehingga pengajarannya perlu diselipkan pada semua mata kuliah yang ada. Sebagai pendidik kita harus merancang pembelajaran yang mengakomodasi itu semua, baik kompetensi mengenai pembelajaran itu sendiri, juga kompetensi pendukung dan soft skill-nya.

Trilling dan Fadel (2009) dalam bukunya "21st century skills: learning for life in our times" menyatakan ada 3 (tiga) kategori keterampilan yang harus dimiliki pada abad 21, yaitu: (1) Learning and innovation skills, meliputi: critical thinking and problem solving, communications and collaboration, dan creativity and innovation; (2) Digital literacy skills, meliputi: information literacy, media literacy, dan information and communication technologies (ICT) literacy; dan (3) Career and life skills, meliputi: flexibility and adaptability, initiative and selfdirection, social and cross-cultural interaction, productivity and accountability, dan leadership and responsibility. Seharusnya beberapa keterampilan ini dapat diajarkan secara tidak langsung dalam pembelajaran menggunakan elearning.

Penggunaan e-learning juga
sejalan dengan falsafah
pembelajaran orang dewasa.

Sebagai orang dewasa, pada hakekatnya mahasiswa cendrung untuk belajar secara individual, karena mereka sudah memiliki kesadaran dan tanggung jawab untuk belajar. Mahasiswa belajar dan membentuk pengetahuan berdasarkan pengetahuan yang ada pada dirinya dan berdasarkan pengalaman yang dialaminya. Penggunaan e-learning juga efektif karena mahasiswa dapat belajar sesuai dengan kecepatannya, dapat mengontrol sendiri pembelajarannya, dan juga efektif karena adanya pengulanganpengulangan (repetition).

Permasalahan dalam pemakaian e-learning tentu juga ada, seperti belum terbiasanya dosen dan mahasiswa dalam penggunaan e-learning untuk pembelajaran, perlu waktu dalam merancang pembelajaran, menjamin interaksi antara dosen dan mahasiswa, mahasiswa dengan materi, dan mahasiswa dengan mahasiswa. Jika tidak ada panduan yang jelas, bisa jadi dosen hanya memindahkan hasil kerjanya ke elearning sehingga tidak tercapai tujuan pembelajaran.

Sebagai sesuatu yang baru tentu banyak kendala yang dihadapi baik oleh mahasiswa maupun dosen dalam pemanfaatan e-learning. Oleh karena itu, pada tahap awal penelitian ini, perlu diketahui bagaimana persepsi mahasiswa dalam penggunaan e-learning untuk pembelajaran. Diharapkan dapat juga diungkap kendala-kendala yang dihadapi oleh mahasiswa dalam 


\begin{abstract}
menggunakan e-learning sebagai suplemen maupun sebagai pengganti beberapa pertemuan dalam perkuliahan nantinya. Berdasarkan informasi yang didapat nantinya juga akan dapat ditemukan metode pembelajaran yang tepat dalam penggunaan e-learning dalam pembelajaran.
\end{abstract}

\section{PENDEKATAN PEMECAHAN \\ MASALAH \\ Pendidikan Orang Dewasa}

Cara orang dewasa belajar berbeda dari anak-anak. Menurut Knowles dkk dalam Lehmann \& Chamberlin (2009:24) ada 6 (enam) prinsip pembelajaran orang dewasa, yaitu: (a) kebutuhan untuk mengetahui, (b) konsep diri peserta didik, (c) pengalaman peserta didik, (d) kesiapan belajar, (e) orientasi pembelajaran, dan (f) motivasi.

$$
\text { Prinsip yang pertama, }
$$
kebutuhan untuk mengetahui, maksudnya yaitu sebagai seorang yang telah dewasa mahasiswa akan banyak bertanya dan tidak berhenti sampai dia mendapatkan jawaban yang memuaskannya. Pertanyaan seperti: "Kenapa saya butuh mengetahui hal ini?" akan sangat sering ditanyakan sehubungan dengan keuntungan pribadi yang didapatkannya jika dia mempelajari suatu hal.

Konsep kedua, konsep diri peserta didik mengungkapkan bahwa mahasiswa butuh untuk mandiri dan bertanggung jawab terhadap pembelajarannya. Mereka tidak akan suka dengan situasi yang memaksakan keinginan terhadap mereka. Pada konsep ini pembelajaran yang cocok yaitu pembelajaran yang memberi pilihan kepada mereka bagaimana suatu tugas dilakukan.

Pengalaman peserta didik yang merupakan prinsip ketiga memberikan ide bahwa sebenarnya sebagai pembelajar dewasa, mahasiswa yang berasal dari berbagai latar belakang telah memiliki pengetahuan awal yang banyak dalam diri mereka. Suatu pembelajaran yang memungkinkan mereka membagi berbagai pengalaman ini dengan peserta didik/mahasiswa yang lain akan sangat mendukung pembelajaran mereka.

Prinsip keempat tentang kesiapan belajar memberikan aturan bahwa konsep yang akan diajarkan kepada mahasiswa sebagai orang dewasa haruslah memiliki aplikasi dan dapat diterapkan pada kehidupannya. Kesiapan ini tentu tergantung kepada mahasiswa itu sendiri.

Prinsip kelima yaitu orientasi belajar berarti bahwa pengetahuan dan keterampilan yang didapatkannya haruslah dapat diaplikasikan pada kehidupannya dan bahkan sejalan dengan minatnya, karena orang dewasa pada dasarnya berorientasi pada hidup. Mahasiswa ingin orientasi tugas-tugasnya dapat dikaitkan dengan bagian nyata dari kehidupannya. Kuncinya yaitu bagaimana merancang pembelajaran sehingga pengetahuan yang didapatkan oleh mahasiswa berguna bagi dirinya.

Prinsip keenam, motivasi, secara sederhana menyatakan bahwa sebagai orang dewasa mahasiswa tidak lagi termotivasi dari luar. Orang yang dapat memotivasinya adalah dirinya sendiri.

Semua prinsip di atas berhubungan dengan filosofi konstruktivisme. Semua pembelajar dewasa, termasuk mahasiswa akan sangat berhasil jika semua rancangan pembelajaran yang dibuat untuk mereka berdasarkan aktivitas konstruktivisme.

\section{Pembelajaran Konstruktivisme}

Konstruktivisme rebagai
paradigma baru pendidikan


berpendapat bahwa belajar adalah proses aktif dan konstruktif. Peserta didik adalah konstruktor informasi. Informasi baru dikaitkan dengan pengetahuan yang telah ada sebelumnya, sehingga mental bersifat subjektif. Originator dan kontributor penting dalam teori konstruktivistik adalah Vygotsky, Piaget, Kwek, Vico, Rorty, Bruner.

Konstruktivisme menganggap bahwa semua pengetahuan dibangun dari pengetahuan peserta didik sebelumnya, terlepas dari bagaimana seseorang menerima pengetahuan itu. Bahkan mendengarkan ceramah-pun melibatkan usaha-usaha aktif untuk membangun pengetahuan baru. Oleh karena itu dalam konsep konstruktivistik peserta didik yang menjadi aktif menjadi penting.

Menurut Pritchard (2007:2)

ada 3 prinsip tentang pembelajaran konstruktivisme yang perlu diperhatikan, yaitu: “... (1) Learning is a process of interaction between what is known and what is to be learned; (2) learning is a social process; (3) learning is a situated process; and (4) learning is a metacognitive process..."

Prinsip di atas menyatakan bahwa belajar adalah proses interaksi antara apa yang telah kita ketahui dengan apa yang akan kita pelajari. Setiap individu memiliki pengetahuan dan pemahaman awal pada dirinya akan sesuatu hal yang dapat digunakan kembali pada situasi baru. Belajar adalah proses sosial berkaitan dengan teori konstruktivisme sosial yang menekankan interaksi antara pebelajar dengan yang lainnya, seperti orang tua, pebelajar lainnya, dan guru/dosen. Pada prinsip ketiga yang berbunyi belajar adalah proses dalam konteks tertentu, mengandung pengertian bahwa semua pembelajaran selalu memiliki konteks tertentu. Prinsip yang terakhir yaitu belajar adalah proses metakognitif. Metakognitif yaitu ide dimana individual sadar akan proses mental atau kognitif dan cara belajar mereka.

\section{Pembelajaran Campuran \\ (Blended Learning)}

Perkembangan

teknologi

informasi dan komunikasi (TIK) telah memberikan pengaruh luar biasa terhadap dunia pendidikan khususnya dalam proses pembelajaran. Menurut Muhammad Surya (2006), dengan perkembangan TIK ini ada 5 pergeseran dalam proses pembelajaran: (a) dari pelatihan ke penampilan; (b) dari ruang kelas ke dimana saja dan kapan saja; (c) dari kertas ke online; (d) dari fasilitas fisik ke fasilitas jaringan; dan (e) dari waktu siklus ke waktu nyata.

Komunikasi sebagai media pendidikan dapat dilakukan dengan menggunakan media-media komunikasi seperti telefon, komputer, internet, email, dan sebagainya. Interaksi antara dosen dan mahasiswa tidak hanya dilakukan melalui hubungan tatap muka tetapi juga dilakukan dengan menggunakan media-media tersebut. Dosen dapat memberikan layanan tanpa harus berhadapan langsung dengan peserta didik. Demikian pula mahasiswa dapat memperoleh informasi dalam lingkup yang luas dari berbagai sumber melalui cyber space atau ruang maya dengan menggunakan komputer atau internet. Hal yang paling mutakhir yaitu "cyber teaching" atau pengajaran maya, yaitu proses pengajaran yang dilakukan dengan menggunakan Internet.

Mason dan Rennie (2009) menyatakan biasanya definisi elearning berbeda tergantung pada penekanannya, ada yang penekanannya fokus pada konten, ada yang fokus pada komunikasi, dan ada yang fokus pada teknologi. 
Munir (2009) menyatakan bahwa persepsi dasar e-learning terbagi dua yaitu: a) e-learning adalah pembelajaran yang memanfaatkan teknologi informasi dan komunikasi, terutama perangkat yang berupa elekronik; dan b) e-learning adalah pembelajaran yang menggunakan fasilitas internet yang bersifat online sebagai instrument utamanya. Naidu (2006) mendefinisikan e-learning sebagai peng-gunaan teknologi informasi dan komunikasi dalam pengajaran dan pembelajaran.

$\begin{array}{ccc}\text { Banyak sekali model } & \text { mera } \\ \text { pembelajaran } & \text { berbasis web }\end{array}$ berkembang saat ini. Ada yang memanfaatkan media web sebagai suplemen atau tambahan saja, ada yang memanfaatkan media web sebagai pengganti sebagian pembelajaran tatap muka di kelas, dan ada pula yang memakai media web secara penuh untuk proses belajar mengajarnya. Menurut Kudwadi (2002) jika bobot pembelajaran tradisional lebih besar dari pembelajaran berbasis web disebut Web Enhanced Course, sedangkan jika berbasis web lebih besar disebut Web Centric Course, sedangkan jika seratus persen berbasis web disebut Web Course. Sedangkan Mason (1998) dari United Kingdom Open University menyatakan bahwa kebanyakan perkuliahan online yang ada sekarang bersifat "partially online" atau "fully online-learning course". Untuk partially online biasanya dikenal dengan blended learning.

Blended learning atau hybrid courses adalah pembelajaran yang memadukan antara komponen online dan komponen tatap muka. Kenyataannya, program belajar yang mengandung komponen online sekecil apa pun (misalnya: situs web pendukung, akses email ke instruktur, daftar bacaan online) kadang-kadang disebut sebagai elearning. Lebih jauh, hal itu juga menggambarkan semua program belajar yang memadukan berbagai media pembelajaran atau berbagai kesempatan pembelajaran: di tingkat yang paling dasar, mereka melibatkan berpikir, membaca dan pencampuran informasi baru dengan pengetahuan yang sudah ada.

\section{Persepsi Mahasiswa Terhadap E- learning}

Bagaimana mengukur persepsi mahasiswa terhadap e-learning? Institute of Higher Education Policy (IHEP) telah mengembangkan suatu set standar untuk mengukur persepsi mahasiswa dalam lingkungan pembelajaran jarak jauh. Standar ini dikembangkan berdasarkan reviu literatur dan interviu 147 orang yang terdiri dari anggota fakultas, mahasiswa, dan anggota administrasi enam institusi pendidikan jarak jauh yang sudah terakreditasi.

Standar ini terdiri dari 45 pertanyaan yang terdiri atas 7 kategori, yaitu: (1) dukungan institusi, (2) pengembangan kursus, (3) proses belajar mengajar, (4) struktur kursus, (5) dukungan terhadap mahasiswa, (6) dukungan fakultas, dan (7) evaluasi dan asesmen. Standar ini telah banyak digunakan untuk mengukur persepsi dalam penggunaan teknologi seperti pembelajaran jarak jauh, pembelajaran berbasis web, dan pembelajaran e-learning.

Dalam penelitian ini akan digunakan dua instrumen, yaitu: (1) instrumen untuk mengukur pendapat mahasiswa mengenai pembelajaran dengan e-learning setelah mengalami pembelajaran pada matakuliah Bahasa Pemrograman; dan (2) instrumen mengenai persepsi mahasiswa mengenai elearning secara umum.

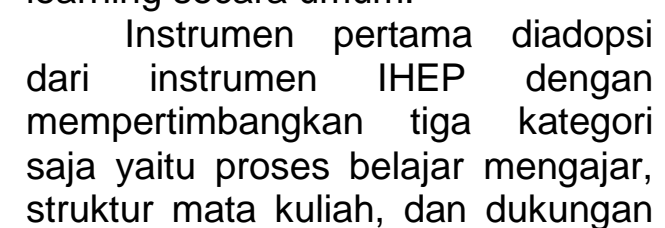


mahasiswa. Kategori ini diambil karena berhubungan langsung dengan pembelajaran mahasiswa. Dari tiga kategori tersebut dikembangkan 6 (enam) aspek, yaitu: tujuan pembelajaran, materi pembelajaran, sistem sosial, aturan peran, aspek interaktif, dan sistem penunjang. Instrumen ini terdiri dari 33 butir pernyataan.

Instrumen kedua terdiri dari 30 (tiga puluh) kata sifat yang dibuat secara random sehubungan dengan penggunaan e-learning sebagai suplemen maupun sebagai pengganti perkuliahan tatap muka di kelas. Kata-kata sifat tersebut nantinya akan dikategorikan menggunakan analisi faktor untuk menggambarkan sikap mahasiswa mengenai e-learning.

\section{Kajian Penelitian yang Relevan}

Beberapa penelitian yang berhasil dikumpulkan dapat disimpulkan sebagai berikut.

Kudwadi dan Suryadi (2010) dalam penelitiannya yang berjudul Pengembangan Kerangka Model elearning dalam Pembelajaran Teknologi dan Kejuruan diantaranya menyimpulkan sebagai berikut: (1) pembelajaran e-learning dapat diselenggarakan dengan menghubungkan pebelajar dengan sumber belajarnya secara langsung (synchronous) dan tidak langsung (asynchronous); (2) sistem pembelajaran yang dikembangkan yaitu Web Enhanced Course, Web Centric Course, dan Web Course; (3) kegiatan yang bisa dilaksanakan dengan e-learning seperti: kegiatan pengajaran, diskusi, membaca, penugasan, presentasi, dan evaluasi; dan (4) model pembelajaran pendidikan teknologi dan kejuruan bisa dilakukan dengan model presentasi, model interaktif, model kolaborasi, atau gabungan ketiganya. Dasar pemakaian model yaitu tujuan, materi bahan ajar, sistem evaluasi pembelajaran, dan karakteristik matakuliah.

$$
\text { Caraivan (2011) dalam }
$$

papernya menganalisis konsep dan proses blended learning, komponen kunci yang membentuk proses ini, dan model yang telah dikembangkan selama 10 tahun terakhir. Paper ini menuliskan karakteristik pengguna yang harus diperhatikan oleh dosen dalam mendesain e-learning, yaitu: (1) kebutuhan mahasiswa; (2) bakat; (3) prestasi; (4) waktu yang dibutuhkan untuk mendapatkan keterampilan tertentu; (5) derajat kebutuhan untuk dibimbing; (6) kemampuan menghadapi tugas yang kompleks; (7) kemampuan menggunakan objek; (8) menjadi kreatif dan imajinatif; dan (9) memecahkan masalah. Kemudian disebutkan bahwa model-model blended learning yang telah ada yaitu: (1) supplemental model; (2) replacement model; dan (3) emporium model. Dan untuk kesemua model, bahan kuncinya (key ingrediens) yaitu adanya: (1) live event; (2) online content; (3) collaboration; (4) assessment; dan (5) reference material. Sebagai kesimpulan dari paper ini yaitu dalam menghadapi persoalan ini pertanyannya bukanlah apakah kita harus mencampur (blend), tetapi apakah bahan/ingredient untuk mencampur tersebut? Sehingga dapat disimpulkan bahwa langkah awal dalam mengadopsi blended learning yaitu mengidentifikasi ingredient tersebut.

Lin, Kuo, Chiu, et al. (2012) mengusut faktor-faktor yang berhubungan dengan pembelajaran online berdasarkan studi empiris. Khususnya yaitu faktor yang berhubunagn dengan area unjuk kerja pembelajaran dalam konteks elearning dari aspek andragogi. Temuan yang didapat yaitu bahwa faktor-faktor kunci yang mempengaruhi partisipasi pembelajaran online meliputi: rasa 
komunitas, keterlibatan instruktur, karakteristik kehidupan dan pengalaman sebelumnya, interaksi, gaya belajar, dan motivasi.

Jurczyk, etal (2014) mencoba mengukur persepsi mahasiswa dalam pembelajaran berbasis web. Dia menyebarkan angket pada awal perkuliahan, pertengahan perkuliahan, dan akhir perkuliahan untuk mengukur persepsi mahasiswa terhadap perkuliahan berbasis web yang dilaksanakan. Pengukuran persepsi siswa ini berguna untuk melihat kecendrungan permasalahan yang dihadapi oleh mahasiswa dalam mengikuti pembelajaran berbasis web sehingga dosen dapat menyesuaikan cara mengajarnya sesuai dengan kecendrungan yang didapatkan.

\section{METODEOLOGI PENELITIAN}

Metode penelitian yang digunakan yaitu metode penelitian survei yang gunanya untuk mengungkap bagaimana persepsi mahasiswa terhadap pembelajaran campuran yang dilakukan selama satu semester. Instrumen yang digunakan yaitu dua set kuesioner yang terdiri dari 33 (tiga puluh tiga) dan 30 (tiga puluh) butir pernyataan. Kuesioner pertama nantinya akan dianalisa dengan analisis statistik deskriptif. Sedangkan instrumen kedua dianalisis dengan analisis faktor.

Kuesioner disebar kepada 75 (tujuh puluh lima) mahasiswa yang mengambil matakuliah Bahasa

Tabel 1. Pendapat Mahasiswa Setelah Menggunakan E-learning Sebagai Suplemen Pada Mata Kuliah Bahasa Pemrograman

\begin{tabular}{|l|c|c|c|c|}
\hline \multicolumn{1}{|c|}{ Aspek } & $\begin{array}{c}\text { Skor } \\
\text { Minimum }\end{array}$ & $\begin{array}{c}\text { Skor } \\
\text { Maksimum }\end{array}$ & Rerata & $\begin{array}{c}\text { Standar } \\
\text { Deviasi }\end{array}$ \\
\hline Tujuan Pembelajaran & 2,20 & 4,00 & 3,15 & 0,36 \\
\hline Materi Pembelajaran & 2,20 & 4,00 & 2,97 & 0,42 \\
\hline Sistem Sosial & 2,00 & 3,17 & 2,59 & 0,29 \\
\hline Aturan Peran & 2,00 & 4,00 & 2,90 & 0,42 \\
\hline Interaktivitas & 2,13 & 4,00 & 3,07 & 0,46 \\
\hline Sistem Penunjang & 2,00 & 4,00 & 3,04 & 0,49 \\
\hline
\end{tabular}

Pemrograman di Jurusan Teknik Elektro FT-UNP.

\section{HASIL DAN PEMBAHASAN}

Data dari 75 (tujuh puluh lima) mahasiswa dikumpulkan dengan dua buah angket yang masingmasing terdiri dari 33 (tiga puluh tiga) dan 30 (tiga puluh) pernyataan. Data yang dikumpulkan mencakup pendapat subjektif mahasiswa terhadap penggunaan e-learning pada matakuliah Bahasa Pemrograman dan persepsi mahasiswa terhadap e-learning secara umum.

Pendapat mahasiswa setelah mengalami pembelajaran menggunakan e-learning pada matakuliah Bahasa Pemrograman dikatego-rikan menjadi 6 (enam) aspek, yaitu: (1) tujuan pembelajaran, (2) materi pembelajaran, (3) sistem sosial, (4) aturan peran, (5) aspek interaktif, dan (6) sistem penunjang. Kesimpulan mengenai hal ini diperlihatkan pada Tabel 1 .

Dari Tabel 1 dapat disimpulkan bahwa dari segi tujuan pembelajaran, materi pembelajaran, aturan peran, interaktivitas, dan sistem penunjang, mayoritas mahasiswa setuju bahwa desain pembelajaran e-learning yang berhubungan dengan aspek-aspek tersebut memadai. Sedangkan dari aspek sistem sosial, mahasiswa menilai bahwa perancangan aspek tersebut dalam e-learning masih belum cukup. 
Tabel 2. Persepsi Mahasiswa tentang Penggunaan E-learning

\begin{tabular}{|l|c|c|c|c|}
\hline \multicolumn{1}{|c|}{ Aspek/Segi } & $\begin{array}{c}\text { Skor } \\
\text { Minimum }\end{array}$ & $\begin{array}{c}\text { Skor } \\
\text { Maksimum }\end{array}$ & Rerata & $\begin{array}{c}\text { Standar } \\
\text { Deviasi }\end{array}$ \\
\hline Motivasi & 2,00 & 4,00 & 2,95 & 0,46 \\
\hline Kemudahan & 1,40 & 4,00 & 2,84 & 0,48 \\
\hline Manfaat & 1.60 & 4,00 & 3,07 & 0,48 \\
\hline Efisiensi & 2,40 & 4,00 & 3,15 & 0,41 \\
\hline Daya tarik & 2,20 & 3,60 & 2,72 & 0,30 \\
\hline Keharusan & 2,00 & 4,00 & 3,04 & 0,47 \\
\hline
\end{tabular}

Persepsi mahasiswa mengenai e-learning secara umum dijaring dengan 30 (tiga puluh) pernyataan. Mutu pernyataan dan instrumen ini diuji dengan validitas dan reliabilitas. Uji validitas dengan mengunakan korelasi Product Moment Pearson menunjukkan 29 (dua puluh sembilan) pernyataan valid pada alpha 0,01 dan satu pernyataan tidak valid. Uji reliabilitas dengan alpha Cronbach menghasilkan koefisien reliabilitas instrumen sebesar 0,917. Artinya instrumen untuk mengukur pendapat mahasiswa mengenai e-leaning sangat baik. Setelah diolah dengan analisis faktor pertanyaanpertanyaan ini terkelompok menjadi enam kelompok yang diberi nama aspek motivasi, kemudahan, manfaat, efisiensi, daya tarik, dan keharusan.

Informasi Tabel 2 menunjukkan bahwa baik dosen maupun mahasiswa berpendapat bahwa pembelajaran dengan e-learning motivatif, mudah digunakan, bermanfaat, efisien, menarik, dan merupakan suatu keharusan.

\section{KESIMPULAN}

Berdasarkan survei yang dilakukan terhadap 75 mahasiswa yang telah mengalami pembelajaran menggunakan e-learning pada matakuliah Bahasa Pemrograman di Jurusan Teknik Elektro FT-UNP didapatkan kesimpulan sebagai berikut: a. Desain pembelajaran yang digunakan sebagai suplemen maupun pengganti perkuliahan tatap muka di kelas dinilai cukup memadai dipandang dari segi tujuan pembelajaran, materi pembelajaran, aturan peran, interaktivitas, dan sistem penunjang.

b. Satu aspek yang dinilai masih belum cukup yaitu aspek sistem sosial.

c. Informasi dari pendapat subjektif mahasiswa mengenai e-learning menunjukkan bahwa baik dosen maupun mahasiswa berpendapat bahwa pembelajaran dengan e-learning motivatif, mudah digunakan, bermanfaat, efisien, menarik, dan merupakan suatu keharusan.

\section{DAFTAR PUSTAKA}

[1] Caraivan, Luiza. (2011). Blended learning: from concept to implementation. Euromentor Journal Volume II No. 4. Diambil pada tanggal 20 Oktober 2012, dari

http://euromentor.ucdc.ro/dec20 $11 /$ en/blendedlearningfrom concepttoimplementation luizacaraivan_12.pdf.

[2] Cheng, Y. C. (2005). New Paradigm for Re-engineering Education: Globalization, 
Localization,

and

Individualization. Netherland:

Springer.

[3] Garrison, D. R., \& Vaughan, N. D. (2008). Blended learning in higher education: framework, principles, and guidelines. San Fransisco: John Willey \& Sons.

[4] IHEP. (2000). Quality on the line: Benchmark for success in internet-based distance education. The Institute of Higher Education Policy.

[5] Jurczyk, J., Benson, S.N.K., \& Savery, J.R. (2013). Measuring student perceptions in webbased courses: a standardsbased approach. Available in: http://www.westga.edu/ distanc e/ojdla/winter74/jurczyk.htm.

[6] Kudwadi, Budi \& Dedy Suryadi. (2010). Pengembangan kerangka elearning dalam pembelajaran teknologi dan kejuruan. Artikel penelitian.

[7] Lehmann, Kay \& Lisa Chamberlin. (2009). Making the move to elearning: putting your course online. USA: Rowman and Littlefield Education.

[8] Lin, S. Y., Kuo, C., Chiu, C. K., etal. (2012). Factors affecting participation in online learning: evidences from andragogy. Journal of Global Business Management. Diambil pada tanggal 20 Oktober 2012, dari http://www.jgbm.org/page/21\%2 0ShinYi\%20Lin.pdf.

[9] Mason, Robin \& Frank Rennie. (2009). Elearning: panduan lengkap memahami dunia digital dan internet. Diterjemahkan dari: Elearning oleh Taylor Francis, London-New York, 2009. Surabaya: Penerbit Baca!

[10] Munir. (2009). Pembelajaran jarak jauh berbasis teknologi informasi dan komunikasi. Bandung: Alfabeta.

[11] Naidu, Som. (2006). Elearning: a guide book of principles, procedures, and practices. New Delhi: Creative Workshop.

[12] Pritchard, A. (2007). Effective Teaching with Internet Technologies: Pedagogy and Practice. London: Paul Chapman Publishing.

[13] Surya, M. (2006). Potensi teknologi informasi dan komunikasi dalam peningkatan mutu pembelajaran di kelas. Makalah dalam Seminar Pemanfaatan TIK untuk Pendidikan Jarak Jauh dalam Rangka Peningkatan Mutu Pembelajaran. Diselenggarakan oleh Pustekkom Depdiknas, Tanggal 12 Desember 2006 di Jakarta.

[14] Trilling, B. \& Fadel, C. (2009). 21st century skills: learning for life in our time. San Fransisco: Jossey Bass. 